\title{
SALAFI DAN STIGMA SESAT-RADIKAL
}

\author{
Slamet Muliono Redjosari \\ Universitas Islam Negeri Sunan Ampel Surabaya, Indonesia \\ E-mail:smuliono@uinsby.ac.id
}

\begin{abstract}
This article describes the dynamics of da'wah movement of Salafis and their response to its stigmatization as being heretical and radical. The phenomenon of radical movements with their terrorist actions shape the stigma of being radical to the salafis. The spread and

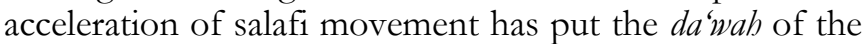
traditionalists in trouble. The stigma of Salafis as being radical and heretical results in the resistence against the Salafis to stop their dawah in many places. The stigmatization of the Salafis as being radical and intolerant drives the Salafis to show their identity as unidentical with the stigmatization. A number of persecution towards the Salafis is the implication of this stigma. This article is resulted from interviews with Salafi figures and $d \bar{a}^{-} \bar{\imath} s$ who felt annoyed with the stigmatization. The appearance of Salafis which resembles those stigmatized as radicals lead to the emergence of public opinion that the Salafis are radical, while on the contrary this article finds that the Salafis in fact fight against radical thoughts that lead to radical and terrorist actions.
\end{abstract}

Keywords: Salafis; stigmatization of heretical; radical.

\section{Pendahuluan}

Perkembangan dakwah Salafi yang begitu masif dan merata menunjukkan respons masyarakat yang demikian positif terhadapnya. Bahkan, penyebaran dakwah ini menembus berbagai level sosial, baik kalangan awam-terdidik, menengah-elite, dan perkotaan-pedesaan. Tumbuhnya kesadaran spiritual masyarakat di berbagai level sosial yang terjadi seiring dengan semakin masifnya penggunaan media sosial, seperti Youtube dan Whatsapp, membuat dakwah kelompok Salafi semakin jauh menembus jantung masyarakat. Di sisi lain, perkembangan dakwah kelompok Salafi yang demikian pesat ini melahirkan penolakan di sejumlah 
wilayah. Penolakan itu bisa berupa penghentian kajian hingga pengusiran komunitasnya, akibat dari pengkategoriannya sebagai kelompok radikal dan intoleran. ${ }^{1}$ Penolakan itu berawal dari ketersinggungan atau merasa terganggunya kelompok yang telah mapan dalam berdakwah, terutama mereka yang aspiratif terhadap budaya lokal. Kelompok ini, yang lebih dikenal sebagai kelompok tradisionalis, merasa terusik dengan keberadaan dan melesatnya dakwah kelompok Salafi.

Gerakan dakwah Salafi saat ini telah menjadi gerakan global. Ia muncul sebagai fenomena transnasional yang menjamur di berbagai negara, baik di wilayah Eropa, Amerika, Afrika, dan Asia. ${ }^{2}$ Diakui atau tidak, perkembangan dan dinamika gerakan kelompok Salafi di Indonesia semakin besar dan banyak menjadi pilihan berbagai lapisan masyarakat, baik perkotaan dan pedesaan, dalam segala kelas usia dan tingkatan pendidikan.

Setidaknya ada beberapa narasi besar tentang dakwah Salafi yang menarik untuk dikaji lebih jauh. Pertama, gerakan Salafi berkembang secara masif dan telah memberikan stimulus bagi tumbuhnya kesadaran beragama di masyarakat. Kedua, tumbuhnya lembaga-lembaga pendidikan ber-manhaj Salafi. Menjamurnya lembaga-lembaga pendidikan berbasis dakwah Salafi menjadi fenomena baru dan berhasil mengubah cara berpikir (mindset) masyarakat dalam melihat kehidupan. Ketiga, lahirnya lembagalembaga penerbitan Salafi, yang juga memanfaatkan media sosial, komunikasi, dan audio-visual. Dakwah lewat buku, majalah, buletin, dan radio-televisi secara masif memiliki pengaruh lintas wilayah dan generasi. Keempat, gerakan kelompok Salafi mengalami perlawanan kolektif. Di samping respons positif, perkembangan 'dakwah tauhid' (demikian kelompok Salafi sendiri kerap menyebut gerakan dakwahnya) yang begitu luas ini juga memperoleh respons negatif yang tidak bisa diremehkan dari berbagai pihak. Radikalisme dan terorisme telah disematkan kepada gerakan yang dilabeli Wahhābī ini. Pelabelan tersebut telah membentuk opini

\footnotetext{
${ }^{1}$ Demonstrasi terhadap Sekolah Tinggi Agama Islam (STAI) Ali Bin Abi Thalib Surabaya terjadi 7 Februari 2015. Demonstrasi tersebut berawal dari buletin yang mengkritik tradisi mauludan. Lihat tempo.co, Minggu, 8 Februari 2015; demikian juga demonstrasi pada 8 April 2018 terhadap Sekolah Tinggi Dirasat Islamiyah (STDI) Jember yang dituduh menganggap zindiq para pelaku mauludan.

${ }^{2}$ Roel Meijer (ed.), Global Salafism: Islam's New Religious Movement (London: Hurst and Company, 2009).
} 
publik yang kemudian memandang gerakan Salafi berakar pada Arab Saudi. ${ }^{3}$

Munculnya perlawanan terhadap gerakan Salafi ini, secara sadar atau tidak, telah menciptakan dua kelompok masyarakat yang berhadap-hadapan dan sulit didamaikan. Kelompok yang pertama adalah orang-orang Salafi sendiri atau mereka yang bersimpati terhadapnya. Sementara kelompok lalinnya adalah mereka yang ragu dan curiga hingga melahirkan sikap perlawanan terhadap gerakan kelompok Salafi. Respons yang ditunjukkan kelompok lainnya ini lebih banyak muncul di permukaan, yang ditandai dengan berbagai aksi penolakan dengan alasan bahwa gerakan Salafi membahayakan ideologi negara.

Kelompok lainnya tersebut direpresentasikan terutama oleh kalangan tradisionalis yang terkenal teguh dalam memegang tradisi lokal. Mereka berada di garda terdepan dengan memegang bendera perlawanan terhadap gerakan Salafi. Kelompok tadisionalis menekankan pentingnya menjadi Negara Kesatuan Republik Indonesia (NKRI) dan bersandar pada ideologi negara, Pancasila. Sementara itu, mereka juga menganggap gerakan Salafi sangat membahayakan, karena banyak memiliki perbedaan pemahaman terhadap budaya yang berkembang di masyarakat yang telah mapan dan bahkan menjadi bagian yang niscaya bagi NKRI yang multikultur.

Dengan demikian, gerakan Salafi dengan label Wahhābī-nya, telah menjadi musuh bersama (common enemy). Bahkan, karena perkembangan gerakan Salafi yang demikian besar, muncul sebuah pernyataan yang tersebar di media sosial bahwa Indonesia dalam keadaan darurat Wahhābī. Dalam pola pikir yang demikian, maka upaya melawan gerakan Salafi yang dianggap membahayakan negara kemudian memiliki arti sama dengan membela negara.

\section{Salafi dan Penerapan al-Qur'ān dan Sunnah}

Gerakan kelompok Salafi dikenal sebagai gerakan dakwah yang mengajak kepada upaya pemurnian agama Islam dengan merujuk pada al-Qur'ān dan Sunnah. Mereka sangat selektif terhadap kultur yang berbertentangan dengan dua sumber ajaran Islam tersebut. Mereka ingin mewujudkan tatanan masyarakat yang

\footnotetext{
${ }^{3}$ M Zaki Mubarak, Genealogi Gerakan Radikal Islam Indonesia: Gerakan, Pemikiran dan Prospek Demokrasi (Jakarta: LP3ES, 2003).
} 
didasarkan pada apa yang diperjuangkan oleh tiga generasi utama dalam Islam, dengan menerapkan al-Qur'ān dan al-Sunnah. ${ }^{4}$ Oleh pihak-pihak tertentu, perkembangan dakwah Salafi yang begitu pesat justru dipandang sebelah mata dan dianggap kurang memperoleh tempat di Indonesia. Hal itu, misalnya, diungkapkan Azyumardi Azra yang begitu pesimis terhadap masa depan gerakan fundamentalis, karena karakternya yang dinilai reaksioner dan radikal terhadap realitas sosial yang dihadapinya. ${ }^{5}$

Gerakan Salafi sejatinya berbeda dengan gerakan-gerakan fundamentalis lainnya dalam menentukan pola dan strategi dalam berdakwah. Ian Adams mengatakan bahwa gerakan Salafi mengambil strategi yang berbeda dengan gerakan-gerakan fundamentalis lainnya. ${ }^{6}$ Di antara perbedaan tersebut adalah: Pertama, mereka taat terhadap pemerintah dan tidak pernah melakukan kritik secara terbuka terhadapnya, baik melalui media massa, buletin, majalah, buku-buku yang mereka terbitkan, atau bahkan di mimbar dalam khutbah-khutbah mereka. ${ }^{7}$ Kedua, tidak memiliki organisasi layaknya organisasi pada umumnya, seperti struktur organisasi dan keanggotaan yang jelas, mekanisme pemilihan pimpinan, dan laporan administrasi. Ketiga, pemahaman Islam yang hanya merujuk pada al-Qur'ān dan al-Sunnah dengan pemahaman tiga generasi pertama, yaitu sahabat, tābi'īn, dan tābi' al-tābi în. ${ }^{8}$ Keempat, melakukan pemurnian Islam dan melawan berbagai praktik-praktik baru dalam agama (bid'ah). Perbuatan bid'ah dianggap telah menodai Islam, sehingga harus dilakukan pembersihan akidah yang tercampur dengan berbagai praktik ritual

\footnotetext{
4 Zainal Abidin Bin Syamsuddin, Membedah Akar Fitnah Wahabi: Buku Putih Dawah Salafiyah (Jakarta : Pustaka Imam Bonjol, 2015), 29

5 Azyumardi Azra, Pergolakan Politik Islam: Dari Fundamantalisme, Modernisme, bingga Post-Modernisme (Jakarta: Paramadina,1999), 123.

${ }^{6}$ Ian Adams, Ideologi Politk Mutakbir (Yogyakarta: 2004), 426.

7 'Abd al-Raḥmān b. Tayyib, "Menepis Tuduhan, Membela Tuduhan", AdzDrakbiiroh al-Islamiyyah, Vol. 3, No. 15 (Rajab 1426/Agustus 2005), 19; lihat juga Abdurrahman Hadi, "Genggamlah Sunnah, Taati Penguasa", diterjemahkan dari risalah Shaykh Mashhūr Hasan Salmān, al-Da'wah ilā Allāh bayn al-Waby wa alFiker, dalam Adz-Dzakbiiroh al-Islamiyyah, Vol. 6, No. 9 (1429).

8 Yazīd b. 'Abd al-Qādir Jawwāz, Sharḅ Aqìdah Abl al-Sunnah wa al-Jamā'ah (Jakarta: Pustaka Imam Asy-Syafi'i, 2006), 34.
} 
yang tidak berasal dari Islam. ${ }^{9}$ Kelima, melakukan tasfiyah dan tarbiyah. Tasfiyah adalah sebuah proses pembersihan ajaran Islam dari berbagai hal yang dinilai tidak bersumber dari Islam. Tarbiyah adalah sebuah proses pendidikan terhadap umat dengan ajaran Islam yang telah mengalami proses tasfiyah. ${ }^{10}$ Keenam, menunjukkan gejala pertumbuhan yang besar, global, dan terfragmentasi. ${ }^{11}$ Ketujuh, adanya pertemuan para penyeru atau dai $\left(d^{a} \mathbf{c}\right)$ Salafi secara berkala di berbagai daerah dengan mendatangkan mashajyikh dari Timur Tengah. ${ }^{12}$

Respons umat Islam terhadap gerakan Salafi ini pada faktanya tidak melulu bernada penolakan, tetapi juga apresiasi dari masyarakat, meskipun yang kedua ini persentasenya sangat sedikit. Apresiasi tersebut tampaknya datang terutama dari mereka yang berusaha memahami betul prinsip-prinsip yang dikembangkan oleh gerakan ini. Tak dapat dipungkiri bahwa dari kalangan tradisionalis pun tidak sedikit yang telah tertransformasi, baik pemikiran maupun perilakunya. Mereka tertarik dan bersimpati pada gerakan ini dan meninggalkan aktivitas atau tradisi yang pernah melahirkan dan membesarkannya. Mereka seakan tidak peduli terhadap banyaknya stigma negatif yang dilekatkan pada gerakan Salafi sebagai gerakan yang membahayakan atau penyokong radikalisme dan terorisme. Sementara itu, negara terus berupaya untuk memberantas dan memerangi radikalisme dan terorisme yang sangat mengganggu keamanan negara.

Jika diperhatikan secara seksama, perlawanan terhadap dakwah kelompok Salafi di berbagai wilayah telah melahirkan konflik sosial berupa kekerasan berlatar agama. Perlawanan terhadap gerakan ini tidak hanya berhenti pada kekerasan verbal berupa penyematan label "radikal" dan "sesat", tetapi juga kekerasan fisik berupa penghentian dengan paksa aktivitas dakwah hingga pengusiran terhadap orang-orangnya. Bagaimanapun, kondisi demikian

\footnotetext{
9 'Abd Allāh b. Șāliḥ al-'Ubaylān, "Pelajaran tentang Manhaj Salaf', AdžDrakbiiroh al-Islamiyyah, Vol. 1, No. 05 (1424/2003).

${ }_{10}$ Abdul Malik Ramadhani, 6 Pilar Dakwah Salafiyah (Jakarta: Pustaka Imam AsySyafi'i, 2000), 84.

11 Terje Ostebo, "Growth and Fragmentation: The Salafi Movement in Bale, Ethiopia”, dalam Roel Meijer (ed.), Global Salafism: Islam's New Religious Movement (London: Hurst and Company, 2009), 354-361.

12 Para dai kelompok Salafi setahun sekali mengadakan pertemuan untuk melakukan pelatihan (dawrah) yang dihadiri para shaykh dari Timur Tengah.
} 
sejatinya menciptakan ketidaknyamanan di kedua belah pihak; pihak Salafi tidak bisa mendakwahkan dan menjalankan paham keagamaannya dengan bebas, sementara pihak lainnya merasa paham keagamaannya terusik oleh paham yang dianggapnya radikal atau sesat tersebut.

Bagi kelompok Salafi, stigma radikal, sesat, dan intoleran yang disematkan kepadanya sangatlah merugikan. Stigma tersebut membuat eksistensi dakwah kelompok Salafi terganggu, dan tidak jarang karena stigma tersebut mereka harus berkonfrontasi dengan kelompok lain. Salah satu contoh kerugian tersebut adalah penolakan terhadap upaya pendirian lembaga pendidikan, Sekolah Tinggi Agama Islam (STAI) Ali Bin Abi Thalib di Surabaya, yang bahkan melibatkan serangan fisik. ${ }^{13}$ Demikian juga yang terjadi pada Sekolah Tinggi Dirasat Islamiyah (STDI) Jember, yang mengalami hal serupa gara-gara stigma yang sama. Sekolah tinggi ini dianggap mengajarkaan ajaran yang bertentangan dengan prinsip abl al-Sunnah dan tidak sesuai dengan Pancasila. ${ }^{14}$

Menanggapi stigma negatif tersebut, kelompok Salafi menyatakan bahwa mereka bukanlah kelompok sesat ataupun radikal. Sebaliknya, mereka justru memantapkan diri sebagai gerakan dakwah yang memerangi berbagai bentuk gerakan radikalisme dan terorisme. Hal ini berlawanan dengan stigma yang dilekatkan padanya. Dengan logika tersebut, kelompok Salafi menjadi korban stigma yang melekat pada dirinya, karena dalam praktiknya, sebagaimana diakui, mereka justru berdakwah melawan pemikiran kelompok radikal. Pada titik ini, stigma sesat ataupun radikal yang disematkan pada kelompok Salafi perlu didalami lebih jauh.

Selanjutnya, artikel ini akan melihat stigma yang ada dengan kacamata kelompok Salafi, kemudian membandingkannya dengan metode pemahaman serta praktik keagamaan kelompok Salafi yang, dalam perspektif kelompok Salafi sendiri, jauh panggang dari api; serta bagaimana kelompok Salafi meng-counter stigma tersebut. Dalam rangka itu, artikel ini akan menggunakan hasil wawancara bersama beberapa tokoh dan dai Salafi.

\footnotetext{
13 "Dua Penyebab STAI Ali Bin Abi Thalib Didemo", tempo.co, 8 Februari 2015.

${ }^{14}$ Baca tribunjatim.com., 4 Agustus 2018.
} 


\section{Stigma Sesat-Radikal}

Stigma 'sesat' yang ditujukan pada kelompok Salafi dianggap sebagai salah sasaran. Tokoh dan dai kelompok Salafi berupaya menolak hal itu dengan berbagai argumen. Stigma radikal dan sesat pada kelompok Salafi ini tidak lebih dari tudingan yang mengadaada dan menyesatkan masyarakat. Hal ini disampaikan oleh Ali Musri, pimpinan STDI Jember, seperti berikut:

Kelompok tradisionalis sering berbicara dan mengkategorikan dakwah Salafi sebagai kelompok radikal. Padahal yang radikal itu kelompok tradisionalis sendiri. Mereka menghentikan kajian, membakar pondok, dan sebagainya. Bahkan, mengkafirkan pemimpin, sebagaimana terjadi di Jember, di mana pimpinan salah satu organisasi tradisionalis di Jember pernah memberikan pernyataan yang mengkafirkan Bupati Jember, ketika salah ngomong..$^{15}$

Dalam pandangan ini, stigma radikal dan sesat sangat tidak tepat ditujukan pada kelompok Salafi. Sebaliknya, kelompok Salafi menjadi korban dan mengalami tindakan-tindakan radikal, seperti penghentian kajian dan pengusiran terhadap pondok Salafi di beberapa daerah. Menurut dai Salafi ini, tindakan radikal justru dilakukan oleh kelompok-kelompok tertentu yang bahkan selalu berbicara tentang bahaya radikalisme, yang dicontohkannya pada kelompok tradisionalis. Radikalisme kelompok-kelompok tersebut bisa dilihat, misalnya, dari sikapnya yang tampak begitu bebas menilai orang lain sesuai dengan kehendaknya bahkan hingga berani mengkafirkan pemimpin. Selain itu, tindakan pengusiran yang dilakukan kelompok tersebut terhadap kelompok lain yang berbeda pandangan dengannya, oleh kelompok Salafi dinilai tidak lebih dari ekspresi tindakan radikal.

Lebih lanjut, penyesatan yang berkembang terhadap kelompok Salafi juga berangkat dari penolakan kelompok Salafi terhadap tradisi ziarah kubur dan afiliasinya dengan Wahhābī. Stigma ini serta-merta ditolak oleh kelompok Salafi, yang bahkan menyatakan bahwa mereka yang mengatakan Wahhābī sesat adalah karena ketidaktahuannya tentang hakikat Wahhābī itu sendiri. Musri merespons hal tersebut dengan argumen sebagai berikut:

Wahhābī tidak melarang ziarah kubur. Tolong dicarikan buktinya. Wahhābī tidak anti-salawat. Dalam kajian-kajian selalu

15 Ali Musri, Wawancara, 20 Agustus 2018, di Jember. 
diucapkan salawat kepada nabi. Dakwah tradisionalis Ini adalah untuk menjaga komunitas mereka dan tradisi mereka. Kalaupun diajak diskusi, mereka tidak pernah serius dan cengengesan. Orang tradisionalis seakan tidak peduli meski sudah dibuktikan kesalahannya. Kalau kita mengalami hal yang sama, maka kita merasa terpukul bila terbongkar kebohongan kita. Mereka suka guyonan dan cengengesan sehingga tidak ada manfaat berdebat dengan mereka. Adapun Wahhābī dibilang anti-ziarah kubur juga tidak sepenuhnya benar. Bahkan Muhammad b. 'Abd alWahhāb memiliki kitab khusus tentang anjuran berziarah kubur. Adapun tradisi merayakan kematian bukanlah tradisi Islam. ${ }^{16}$

Kelompok Salafi meyakini, tuduhan bahwa Wahhābī telah sesat dan menyimpang karena menolak ziarah dan salawat adalah tidak benar. Hal ini dibuktikan dengan bacaan salawat yang disampaikan di setiap kajiannya. Demikian pula anggapan bahwa Wahhābī menolak ziarah kubur tidaklah tepat, sebab hal tersebut akan melawan fakta bahwa Muhammad b. 'Abd al-Wahhāb memiliki kitab yang menganjurkan untuk melakukan ziarah kubur. Kelompok Salafi melakukan bantahan terhadap tuduhan demi tuduhan kelompok tradisionlis yang meraka anggap tidak ada dasarnya. Lebih jauh terkait kebenaran Wahhābī, Musri menambahkan:

Kelompok tradisionalis sering kali menuduh dakwah salaf sesat karena merujuk Wahhābī. Katanya, Wahhābī sering menyesatkan pihak lain. Tolong minta kepada mereka bukti kesesatan Wahhābī dengan menunjukkan buku yang ditulis oleh Muhammad b. 'Abd al-Wahhāb. Ketika mengajar di IAIN [Institut Agama Islam Negeri] Jember, saya pernah mengajak mahasiswa untuk melihat literatur Islam yang dianggap Wahhābī. Setelah mahasiswa memahami cara beragama yang benar dengan merujuk pada buku-buku Wahhābī, mereka malah menyembunyikannya. Ini berarti mereka menyembunyikan ilmu. ${ }^{17}$

Pernyataan ini menolak tuduhan sesat terhadap kelompok Salafi, yang dipandang sebagai kebohongan belaka. Tuduhan tersebut tidak pernah terbukti, termasuk jika harus merunut pemikiran tokoh dan ulama sentral kelompok Salafi, Ibn 'Abd alWahhāb. Menurut pengakuan Musri, ia telah mempelajari dengan

\footnotetext{
${ }^{16}$ Ibid.

${ }^{17}$ Ibid.
} 
seksama pemikiran Ibn 'Abd al-Wahhāb, dan tidak menemukan bukti kesesatan sebagaimana dituduhkan oleh kelompok tradisionalis.

Sementara itu, stigma radikal yang dilekatkan pada kelompok Salafi juga dianggap kurang tepat, karena radikalisme adalah sebuah paham yang berbahaya dan dapat merongrong pemerintah. Sementara kelompok Salafi justru berdiri bersama pemerintah dalam memerangi radikalisme. Hal ini sebagaimana dikatakan oleh Fadlan Fahamsyah sebagai berikut:

Salafizyun [orang-orang Salafi] tidak setuju dengan istilah-istilah yang disematkan mereka bahwa kita adalah kelompok radikalis atau minimal dianggap menumbuhkan bibit-bibit radikal. Dalam hal ini, Salafi mengatakan dan sudah banyak disampaikan oleh media-media Salafi bahwa perbedaan figh iya, itu sudah keniscayaan, tetapi kalau dikatakan bahwa gerakan ini merongrong pemerintah, mengadakan gerakan-gerakan separatis, gerakan-gerakan anarkis, jelas ini tidak benar. Jadi perbedaan Salafi kenceng dalam masalah fiqh tidak bisa kita pungkiri. Tetapi dalam tataran pemikiran, bahkan dalam aksi pun Salafi selalu mewanti-wanti anak didiknya, kalau di kampus ya mahasiswanya, kalau di pesantren ya santri-santrinya, jangan mudah terprovokasi. ${ }^{18}$

Pandangan ini menunjukkan bahwa secara fiqh, kelompok Salafi terlihat tegas dalam menerapkan ajaran yang jelas datang dari nabi, seperti penekanan pada salat berjamaah di masjid bagi lakilaki atau tentang mengenakan celana di atas mata kaki. Hal ini berbeda dengan gerakan dakwah lainnya dalam merespons dua ajaran ini. Penegasan Salafi sebagai gerakan dakwah yang berbeda dengan gerakan-gerakan dakwah lainnya ditunjukkan dengan tiadanya fatwa atau tindakan pengkafiran terhadap penguasa. Hal demikian kembali ditegaskan oleh dai asal Lamongan ini:

Bahkan Salafi berbeda dengan gerakan transnasional lainnya yang mudah menjustifikasi kafir kepada pemerintah. Kalau Salafi tidak. Salafi mengakui bahwa Presiden Indonesia adalah wali al-amr yang harus ditaati dalam kebaikan. Makanya dapat dicek datanya jika Salafi pernah demo di Indonesia. Meskipun katakanlah Salafi sendiri perlu klasifikasi, ada yang dikatakan Salafi ini Salafi itu, tetapi yang saya maksud adalah Salafi yang diistilahkan oleh orang-orang sebatas keilmuan, pemikiran,

\footnotetext{
${ }^{18}$ Fadlan Fahamsyah, Wawancara, 26 September 2018, di Surabaya.
} 
akademik kan gitu. Jadi kita tidak sependapat dengan sematan itu dan buktinya banyak, bisa dicek datanya. Banyak pesantren yang bersama-sama TNI-Polri, termasuk juga pernah membuat acara besar tentang deradikalisasi yang mengundang pihak kepolisian, pihak tentara, bahkan kita juga ada workshop (pencerahan) dari Kodim apa Korem untuk mahasiswa. Jadi kita siap untuk mendukung pemerintah dalam menangani aksi-aksi yang makar dan seterusnya itu. ${ }^{19}$

Pernyataan ini semakin menguatkan pandangan bahwa dakwah Salafi bukan dakwah radikal sebagaimana anggapan sebagian kelompok Muslimin. Mudah melakukan pengkafiran tidaklah tepat jika dikatakan sebagai kebiasaan kelompok Salafi. Menurut pernyataan di atas, kelompok Salafi tidak pernah menjadi ancaman bagi pemerintah. Sebaliknya, mereka bersama pemerintah melawan pemikiran kelompok radikal.

Menurut Arifin Badri, radikalisme bukanlah paham yang dianjurkan oleh agama manapun, termasuk Islam. Ia tidak lebih sebagai salah satu pemahaman dalam agama yang, disadari atau tidak, mengembangkan beberapa prinsip yang bisa dimasukkan pada kategori radikal. Meskipun dalam Islam ditemukan beberapa kelompok keagamaan yang oleh beberapa pihak dikategorikan radikal, tetapi Islam sendiri bukanlah penganjur paham radikalisme. Kategori radikal sendiri sejatinya masih debatable; belum ada kategori yang tegas suatu kelompok dapat disebut radikal. Oleh karenanya, penyematan label radikal pada gerakan dakwah kelompok Salafi adalah tindakan yang terburu-buru dan bisa menyesatkan masyarakat. Terkait hal ini, Badri mengatakan sebagai berikut:

Di semua budaya juga ada. Kalau dalam Islam, standar untuk bisa menyebut itu ekstrem kanan atau ekstrem kiri ya harus tahu standar yang benar itu bagaimana. Kalau ada orang kafir (murtad), bagaimana dalam Islam yang benar perlakuannya? Ketika ini sudah melampaui batas kewenangan, bahkan lepas kontrol standarnya. Jika kita ingin menilai yang salah, kita harus punya acuan yang benar. Punya tolok ukur yang baku dalam Islam. Jika kita tidak memiliki alat ukur yang benar, hasilnya atau penilaiannya juga pasti salah. Kalau kita menimbang berapa kilo ini? Tapi kondisi timbangan rusak bagaimana? Radikalisme itu

19 Ibid. 
dinilai dari kacamata apa dulu? Orang itu radikal (ekstrem) standar penilaiannya siapa dan apa?20

Label yang disematkan pada kelompok Salafi sebagai kelompok radikal, menurut Badri, tidak tepat. Lebih-lebih, standar ketegori radikal itu sendiri sejauh ini tidak jelas dan terkesan dipaksakan. Alhasil, pelabelan radikal pada kelompok Salafi sejauh ini tampak lebih didasari oleh kepentingan-kepentingan tertentu dari pada alasan-alasan keagamaan yang prinsipil.

Sementara itu, Mubarok Bamualim, Ketua STAI Ali Bin Abi Thalib Surabaya, menguatkan pandangan bahwa tuduhan radikal terhadap dakwah Salafi diakibatkan oleh minimya pengetahuan terhadap dakwah Islam sebagaimana disampaikan oleh Nabi Muhammad. Jika setiap orang memiliki pengetahuan yang cukup terhadap dakwah nabi, maka tuduhan-tudahan negatif yang demikian seharusnya tidak pernah ada. Ia mengatakan sebagai berikut:

Kalau orang berbicara boleh saja. Sah saja menilai. Silakan menilai. Pokoknya jangan memfitnah dan jangan menuduh yang tidak-tidak. Karena biasanya orang itu tidak cinta kepada sesuatu yang tidak dia kenal. Pepatah Arab menyatakan bahwa 'manusia memusuhi apa yang tidak ia sukai'. Kalau dia sudah tahu, lain lagi ceritanya. Dan itu sudah biasa. Karena salah satu sebab keliru dalam memahami kelompok Salafi karena yang dilihat melulu dari sisi fisiknya. Secara fisik memang mirip dengan kelompok-kelompok radikal. Jenggotan, cingkrang, padahal belum tentu radikal. Kemasannya boleh sama, tapi isinya beda. Itu hanya sekadar omongan, tidak semua harus dilayani. ${ }^{21}$

Menurut pandangan ini, tuduhan negatif dan keji yang kerap ditujukan pada dakwah Salafi tidak perlu digubris. Mereka yang menuduh tidak lain dikarenakan ketidaktahuannya terhadap dakwah ini. Bamualim juga menunjukkan bahwa tidak sedikit orang yang ketika mengetahui dakwah yang disampaikan kelompok Salafi secara lebih baik justru hatinya tertambat pada gerakan dakwah ini.

Apa yang disampaikan oleh para narasumber di atas menunjukkan bahwa stigma atau penyematan radikal pada kelompok Salafi perlu ditinjau ulang. Sejauh ini, stigma tersebut lebih diakibatkan oleh dua hal, yaitu ketidaktahuan dan

\footnotetext{
${ }^{20}$ Arifin Badri, Wawancara, 20 Agustus 2018, di Jember.

${ }^{21}$ Mubarak Bamualim, Wawancara, 26 September 2018, di Surabaya.
} 
kepentingan terselubung. Kedua hal tersebut dapat melahirkan tuduhan yang terburu-buru hingga menciptakan permusuhan dan konflik. Bahkan, kepentingan terselubung akan menyebabkan sikap tidak mau tahu dan tindakan provokatif terhadap pihak lain untuk memusuhi kelompok Salafi bersama-sama.

\section{Masalah Takfir}

Salah satu alasan penting kenapa kelompok Salafi dikategorikan radikal adalah karena dianggap mudah memvonis kafir (takfir) kelompok lain. Tak pelak, anggapan ini memunculkan opini negatif terhadap kelompok Salafi di tengah masyarakat. Kelompok Salafi dianggap sebagai kelompok yang membahayakan dan menciptakan perpecahan di tengah masyarakat. Anggapan tersebut terutama muncul dari kelompok tradisionalis yang notabene berbeda dengan Salafi dalam cara pemahaman keagamaannya.

Terkait tuduhan takfiri ini, Musri membantahnya dengan argumentasi sebagai berikut:

Dakwah salaf sering disebut-sebut mengkafirkan orang lain. Hal ini tidak berdasar. Dakwah salaf tidak pernah mengeluarkan kalimat itu. Kalimat itu bersifat umum, bukan bersifat personal. Ketika orang ngomong larangan bid'ah dan pelakunya masuk neraka itu merupakan kalimat yang sifatnya tidak memvonis. Apakah orang itu kafir atau tidak, adalah bergantung bagaimana perbuatannya, apakah betul-betul membuat pelakunya kafir dan masuk neraka. Sama ketika seseorang melakukan perbuatan zina, mencuri, minum minuman keras, maka pelakunya bisa masuk neraka. Apakah dia langsung kafir dan masuk neraka? Demikian pula ketika mengatakan bahwa pelaku bid'ah kedudukannya sama dengan orang yang melakukan dosa dan akan memperoleh hukuman di neraka. ${ }^{22}$

Pengkafiran diakui sebagai konsep yang diimani oleh kelompok Salafi. Namun, pengkafiran tersebut selalu bersifat umum, yaitu bagi siapapun yang melakukan perbuatan yang bisa dimasukkan ke dalam kategori kafir, bukan ditujukan untuk orang tertentu. Sementara dalam banyak opini publik yang berkembang, tergambar bahwa kelompok Salafi 'gemar' mengkafirkan, tapa mempertanyakan apakah sifatnya umum atau personal. Lebih jauh, Musri memberi contoh kasus yang pernah terjadi di era nabi dan para sahabatnya, yang diungkapkannya sebagai berikut:

${ }^{22}$ Musri, Wawancara, 20 Agustus 2018, di Jember. 
Ada seorang sahabat yang melaknat sahabat yang lain tetapi nabi melarangnya. Padahal melaknat secara umum boleh bila dia melakukan perbuatan laknat. Nabi hanya melaknat secara umum saja, tidak secara personal. Sebagaimana yang terjadi pada sahabat 'Adī b. Abā Balta'ah yang mengirim surat kepada keluarganya di Mekah yang mengabarkan bahwa pasukan kelompok Muslimin akan datang ke Mekah, sehingga 'Umar memohon ijin kepada nabi untuk memenggal lehernya. Oleh karena itu, cara berpikir neraka dan kafir ketika seseorang melakukan perbuatan bid'ah adalah cara berpikir yang salah. Orang yang menyatakan ahli bid'ah termasuk kafir juga cara berpikir yang menyimpang. Perbuatan bid'ah itu bertingkattingkat, sehingga tidak mudah menjatuhkan vonis kepada orang lain secara serampangan. ${ }^{23}$

Tuduhan mudah mengkafirkan yang sering ditujukan terhadap kelompok Salafi berawal dari sebuah ungkapan dalam khutbat alHajjah nabi yang sering disampaikan kelompok Salafi, yaitu kull bid'ah ḍalälah wa kull ḍalälah fi al-nār (setiap bid'ah adalah sesat, dan setiap yang sesat bertempat di neraka). Ungkapan tersebut tidak bersifat personal, tetapi bersifat umum. Siapapun yang melakukan perbuatan bid'ah, maka ia akan dimasukkan ke dalam neraka. Dengan kata lain, pelakunya akan dihukum di neraka karena telah berbuat dosa, yakni berbuat sesuatu yang tidak diperintahkan nabi (bid'ah). Namun, hal tersebut tidak lantas berarti mengeluarkan pelakunya dari Islam. Demikian pula halnya orang yang yang melakukan zina yang tidak serta merta keluar dari Islam, akan tetapi memperoleh hukuman di neraka. Pernyataan di atas juga menyebutkan bahwa konsep bid'ah sendiri tidaklah sederhana. Ia bertingkat-tingkat sesuai dengan keadaan dan kondisi pelakunya. Pelaku bid'ah karena sekadar mengikuti orang lain berbeda dengan pelaku bid'ah yang benar-benar sadar bahwa perbuatan itu memang tidak pernah diajarkan oleh nabi.

Hal ini bisa dilihat dari kasus Ibn Abī Balta'ah sebagaimana ditunjukkan oleh Musri. Perbuatannya benar-benar merupakan kesalahan besar, yaitu mengirim surat kepada keluarganya yang ada di Mekah. Padahal, nabi saat itu secara diam-diam akan pergi ke Mekah untuk menyerang orang kafir, dan tak ingin ada orang Mekah yang mengetahui hal ini. Namun, rahasia nabi itu bocor akibat surat yang dikirim oleh Ibn Abī Balta'ah. 'Umar b. al-

${ }^{23}$ Ibid. 
Khațāàb pun gusar dan meminta izin kepada nabi untuk memenggal lehernya. Akan tetapi nabi melarangnya, karena Ibn Abī Balta'ah adalah salah seorang yang ikut perang Badar. Sementara firman Allah menyatakan bahwa siapapun yang mengikut perang Badar dijamin masuk surga.

Adapun Fadlan Fahamsyah menjelaskan bahwa tuduhan gemar mengkafirkan yang ditujukan pada dakwah salaf merupakan buah ketidaktahuan atau keengganan untuk mengklarifikasi terkait masalah bid'ah. Ia juga menegaskan bahwa bid'ah itu bertingkattingkat, dan memerlukan perincian bila dialamatkan kepada seseorang. Ia mengatakan:

Dalam masalah takfir, kan sering ya mendengar di antara tuduhan yang dialamatkan ke Salafi yang katanya sering mengkafirkan, padahal Salafi sendiri termasuk takut dalam mengkafirkan seseorang. Karena menurut Salafi takfir itu ada dua. Lah ini akibat tidak ada klasifikasi. Makanya ketika Salafi mengatakan bahwa bid'ah itu sesat, sebagaimana orang yang datang dan minta ke kuburan adalah kafir. Di kalangan Salafi dan ulama-ulama Shafi'îyah membagi dua macam takfir, yaitu takfir mutlaq dan takfir mu'ayyan. Takfir mutlaq itu artinya menghukumi $f i \%$, menghukumi perbuatan. Orang yang datang ke kuburan dan sujud minta ke kuburan menurut Salafi itu kafir, dan ini juga menurut ulama-ulama [empat] mazhab. Kalau kita mau merujuk ke kitab-kitab klasik baik karangan Shāfici, Aḥmad, Abū Ḥanīfah, dan yang lainnya, maka ditemukan bahwa orang yang datang, meminta, dan memposisikan kuburan itu sebagai Tuhan, misalnya, maka menurut para ulama ini masuk dalam perbuatan syirik. ${ }^{24}$

Pernyataan ini mamandang bahwa dalam vonis kafir, dalam hal ini takfir mutlaq, sebuah perbuatan harus benar-benar terlihat atau dilakukan secara kasat mata. Namun demikian, kelompok Salafi tidak secara otomatis mengkafirkan pelaku bid'ah tersebut, kecuali pada perbuatannya. Hal ini ditegaskan oleh Fahamsyah dalam pernyataannya berikut ini:

Salafi tidak mengotomatiskan itu kepada personnya. Fi'l-nya iya, tetapi orangnya belum tentu kecuali kalau sudah takfir mu'ayyan. $M u ' a y y a n$ artinya person, mutlaq artinya umum. Kalau sudah person, ada syarat-syarat yang harus dipenuhi, yaitu orang ini bodoh atau tidak, paham atau tidak, sudah iqämat al-bujjah atau

${ }^{24}$ Fahamsyah, Wawancara, 26 September 2018, di Surabaya. 
belum, sudah hilang penghalang-penghalangnya atau belum, mungkin sejak dahulu kala dia tidak pernah punya ilmu kecuali hanya sebatas itu yang diketahui oleh guru-gurunya dan seterusnya. Jadi ini dimudahkan. Makanya dalam Salafi ini ada kaidah yang mapan, yang ditulis oleh para ulama-ulamanya, 'tidak serta merta orang yang terjatuh dalam amalan-amalan kekafiran, menyebabkan kekafiran itu terjatuh padanya'. Kita katakan amalannya ini memang amalan yang tidak benar, tetapi bukan otomatis orang ini menjadi kafir. Lah ketika Salafi memunculkan narasi-narasi yang dipakai seperti 'orang melakukan ini kafir', lah itu oleh sebagian kawan-kawan dipahami sebagai takfir mu'ayyan. Padahal beda. Di antara dalilnya, banyak Salafi yang salat di masjidnya kelompok tradisionalis. Kalau seandainya kafir secara mu'ayyan kan tidak mungkin, jelas-jelas batal salatnya.

Dengan pernyataanya tersebut, Fahamsyah mencoba mengklarifikasi tuduhan gemar mengkafirkan yang sering ditujukan pada kelompok Salafi. Berdasarkan pembagian konsep kafir yang disampaikannya, ia menegaskan bahwa kafir yang biasanya digunakan oleh kelompok Salafi sejauh ini sebenarnya adalah takfir mutlaq (umum), bukan takfir mu'ayyan (personal) sebagaimana disangkakan oleh kelompok-kelompok yang menentang. Jika bersifat personal, maka diharuskan adanya bukti yang jelas. Oleh karenanya, diauki oleh Fahamsyah bahwa kelompok Salafi tidak sampai ke arah personal bila menyatakan kafir.

Sementara menurut Badri, pengkafiran atau tuduhan radikal yang dialamatkan pada kelompok Salafi, adalah upaya parsialisasi pemahaman agama, sebagaimana dikatakannya:

Gerakan Salafi itu harus dipahami. Ia sebagai sebuah ideologi atau sebuah gerakan yang sudah ada? Kalau gerakan yang sudah ada, sekarang pertanyaannya siapakah mereka yang dikatakan gerakan Salafi? Ini masalah, karena antara sebuah ideologi (ajaran) dengan oknum itu berbeda. Bisa jadi ajarannya benar tetapi oknumnya salah. Ini yang harus diluruskan. Itu poin pertama. Kedua, tiga parameter itu dalam Islam masih perlu diluruskan. Perubahan cepat itu pada personal (diri sendiri, individu) atau pada masyarakat (dia ingin merubah masyarakat). Misalnya seorang produsen khamer. Ia orang Islam memproduksi khamer. Ia sadar dan pada hari itu juga dia tutup pabriknya. Semua berhenti bekerja dan menerima konsekuensinya. Salahkah? Apakah itu radikal? Apakah harus ditakuti? Seorang Muslim yang melakukan perubahan secara cepat 
meskipun melibatkan banyak orang. Sekarang seorang pejabat, yang melihat di wilayah kekuasaannya ada korupsi massal. Ketika dia hentikan dengan cara-cara yang cepat, dia tangkap itu yang korupsi, sehingga terjadi perubahan yang cepat. Jadi, perubahan cepat ini juga harus ditafsirkan dengan baik ya. Kalau dipahami sebagai ideologi, sebenarnya salaf tidak pernah mengajarkan kekerasan. Dalam konteks dakwah (amr ma'rüf naby munkar), mengubah kemungkaran dengan kekuasaan itu bagi yang punya kekuasaan. Adapun yang tidak punya kekuasaan tidak boleh mengubahnya dengan tangan dan hanya bisa mengubahnya dengan lisan, kontkesnya menasihati. Sederhananya, taruhlah kekuasaan suami atas istri. Apabila si istri membuka aurat, suami berhak dengan tangan (memukul, memberikan hukuman fisik) berdasarkan alasan yang dibenarkan selama ia tidak membuat cacat. Artinya, proporsional dalam rangka edukasi. Tetapi saya sebagai tetangganya bolehkah saya memukul dia? Jelas tidak boleh. Seperti yang saya katakan, masalah itu muncul ketika agama diterapkan secara tidak proporsional, ada parsialisasi pemahaman dan penerapan agama. Pasti akan terjadi ketimpangan, salah satunya adalah radikalisme.

Itu adalah parsialisasi pemahaman dan penerapan agama. ${ }^{25}$

Sampai di sini, persoalan tuduhan sesat dan gemar mengkafirkan orang yang ditujukan terhadap kelompok Salafi tampak semakin menemui jalan terang. Meskipun kelompok Salafi mengakui tindakan takfiri yang dilakukan, tetapi mereka sejatinya tidak pernah menuduh orang lain kafir secara personal, malainkan secara umum; pengkafiran yang diungkapkan oleh kelompok Salafi tidak lebih sebagai sebuah peringatan umum kepada siapapun agar menjauhkan diri dari perbuatan dosa atau bid'ah.

\section{Salafi dan Kesadaran Spiritual Masyarakat}

Tuduhan terhadap kelompok Salafi sebagai kelompok sesat dan radikal, gemar mengkafirkan kelompok lain, serta menganggap kelompoknya sebagai yang paling benar, tidak lebih hanyalah sebuah stigma. Stigma yang demikian itu bukan hanya membuat situasi sosial semakin keruh, tetapi menciptakan gap dan konflik di antara kelompok-kelompok Islam. Stigma sesat dan radikal dianggap mengganggu eksistensi kelompok yang sudah mapan dan hidup dengan tradisi yang selama ini berjalan. Akhirnya, persekusi terhadap kelompok Salafi, baik dengan hasutan, penghentian

${ }^{25}$ Badri, Wawancara, 20 Agustus 2018, di Jember. 
pengajian, atau pengusiran orang-orangnya terjadi di berbagai daerah, dan membuat konflik di tengah masyarakat semakin meruncing.

Di sisi lain, lemahnya perangkat dan piranti penegakan hukum semakin memperburuk situasi. Sering kali aparat penegak hukum, dalam hal ini pihak kepolisian, lebih memilih aman dan setuju dengan penghentian dakwah kelompok Salafi yang notabene adalah minoritas. Pembiaran dan memilih langkah aman lebih dikarenakan oleh desakan mayoritas, dari pada berdasarkan fakta dan rasa keadilan. Hal ini berimplikasi pada menguatnya arogansi kelompok mayoritas terhadap minoritas Salafi.

Penghentian dakwah Salafi memiliki efek domino yang tidak bisa diremehkan. Salah satunya yang terpenting, kondisi tersebut mengganggu dan menghentikan aktivitas pendidikan yang menjadi bidang garapan dakwah Salafi. Ketika dakwah Salafi dianggap sesat dan menyimpang, maka lembaga pendidikan yang dimilikinya pun turut terganggu. Proses perizinan atau pendirian lembaga pendidikan ikut terhambat, di mana pihak yang terkait tidak mengeluarkan atau menahan izin operasionalnya. Ketika ada demonstrasi massa pada STAI Ali Bin Abi Thalib Surabaya dan STDI Jember, proses belajar-mengajar di kedua lembaga tinggi tersebut terganggu. Murid atau santri dari kedua lembaga tersebut pun merasa tertekan. Bahkan, proyek perluasan pembangunan gedung di STDI Jember terhambat.

Dalam kondisi tersebut, kelompok Salafi tidak ikut larut dalam merespons persekusi pada dirinya dan lebih memilih diam, atau paling tidak menyerahkan semuanya kepada pemerintah, dalam hal ini aparat penegak hukum untuk menjadi hakim yang netral dengan menegakkan aturan yang berlaku, dan menindak siapapun yang dinyatakan menciptakan keonaran. Selain itu, mereka yakin bahwa dengan berjalannya waktu, situasi akan berubah dan masyarakat akan bersikap dewasa. Masyarakat dibiarkan menilai sendiri apakah kelompok Salafi benar-benar sesat dan radikal atau hal tersebut hanya stigma belaka. Penolakan terhadap dakwah kelompok Salafi sejatinya dilakukan oleh hanya sebagian kecil orang, yang kemudian menggalang massa untuk melancarkan semua rencana-rencananya. Massa pada umumnya tidak mengerti apa yang sedang didemonstrasikan. Berkat peran pemerintah dan pihak terkait yang membantu menyelesaikan persoalan ini, konflik yang bermunculan 
selalu dapat diredam. Dalam situasi yang kondusif dan stabil, biasanya cara pandang masyarakat terhadap kelompok Salafi berubah. Terbukti, persoalan yang dialami STAI Ali Bin Abi Thalib Surabaya dan STDI Jember secara pelan-pelan telah membuat masyarakat memahami bahwa tuduhan sesat-radikal pada kelompok Salafi tidaklah benar.

Demikian pula, kedewasaan antartokoh agama dan pemuka masyarakat juga turut memiliki andil dalam menekan atau bahkan mencegah potensi konflik. Para tokoh tersebut, bersama pemerintah, memainkan peran kunci bagi riuh-rendahnya situasi di antara dua kelompok yang sedang bertikai. Menjadi penengah dan pendengar yang baik ketika terjadi konflik antar kelompok agama sejauh ini merupakan jalan keluar yang sangat penting, dari pada terprovokasi dengan memihak mereka yang salah, yang hanya akan semakin menciptakan situsi chaos di tengah masyarakat.

\section{Penutup}

Secara umum, paham keagamaan kelompok Salafi memiliki kesamaan dengan gerakan Islam yang lain, yaitu memperjuangkan tegaknya nilai-nilai Islam di manapun. Yang membedakan kelompok Salafi dengan gerakan yang lain adalah dalam hal cara memahami agama, penekanan dan strategi dakwahnya. Pemahaman agama kelompok Salafi merujuk pada pemahaman Islam tiga generasi terbaik Islam, yakni para sabahat, tabi'inn, dan tābi ‘ al-tābi'īn. Sementara dakwahnya menekankan pada tauhid. Adapun strateginya adalah dengan mendidik dan mendakwahkan kepada kelompok Muslimin akan ajaran Islam yang telah mengalami tasfizah (pemurnian) dan tarbiyah. Dalam hal ini, kaum Muslimin diajarkan dengan agama yang, dalam pandangan Salafi, benar-benar bersih dari anasir yang tidak bersumber dari Allah dan rasul-Nya.

Gerakan Salafi begitu masif dengan melakukan kajian dan pendirian lembaga-lembaga pendidikan dan pesantren. Perkembangan dakwah kelompok Salafi merambah semua wilayah geografis dan strata sosial, mulai dari perkotaan hingga pedesaan, dengan ditopang beragam media, mulai dari radio, televisi, Facebook, Whatsapp, hingga media cetak seperti buku, majalah, atau buletin.

Bagi sebagian kelompok masyarakat, pesatnya pertumbuhan dakwah kelompok Salafi dianggap sangat menggangu eksistensi 
mereka. Terutama penekanan pada tauhid dan penolakannya pada agama yang tercampuri oleh tradisi lokal, membuat dakwah kelompok Salafi dituduh sesat, radikal, dan intoleran. Implikasinya, muncullah larangan kajian, bahkan demonstrasi yang menuntut penghentian dakwah Salafi di tengah masyarakat.

Pembahasan dalam artikel ini menunjukkan bahwa penyematan sesat, radikal, dan intoleran terhadap kelompok Salafi hanyalah sebuah stigma, yang berangkat dari ketidaktahuan atau kepentingan-kepentingan tertentu kelompok lain. Kelompok Salafi bukanlah penganjur radikalisme, tetapi justru berdiri tegak melawan radikalisme, sebagaimana hal ini tergambar dalam kajiankajian yang rutin digelarnya. Tampilan kelompok Salafi yang (mungkin) mirip dengan kelompok radikal bagi sebagian orang, seperti berjenggot, celana cingkrang, dan cadar memang cenderung menimbulkan salah pengertian. Oleh karena itu, perkembangan gerakan Salafi yang terbilang fenomena baru dalam konteks keberagamaan di tanah air perlu dipahami secara seksama, sebelum dilakukan penarikan kesimpulan terhadapnya.

\section{Daftar Rujukan}

Adams, Ian. Ideologi Politik Mutakhir. Yogyakarta: 2004.

Azra, Azyumardi. Pergolakan Politik Islam: Dari Fundamantalisme, Modernisme, hingga Post-Modernisme. Jakarta: Paramadina,1999.

Bin Syamsuddin, Zainal Abidin. Membedah Akar Fitnah Wahabi: Buku Putih Dakwah Salafiyah. Jakarta: Pustaka Imam Bonjol, 2015.

Hadi, Abdurrahman. "Genggamlah Sunnah, Taati Penguasa", diterjemahkan dari risalah Shaykh Mashhūr Hasan Salmān, alDa'wah ilā Alläh bayn al-Waby wa al-Fiker, dalam Adz-Dzakhiiroh al-Islamiyyah, Vol. 6, No. 9, $1429 \mathrm{H}$.

Ibn Ṭayyib, 'Abd al-Raḥmān. "Menepis Tuduhan, Membela Tuduhan", Majalah Adz-Drakbiiroh al-Islamiyyah, Vol. 3, No. 15, Rajab 1426/Agustus 2005.

Jawwāz, Yazīd b. 'Abd al-Qādir. Sharḥ Aqìdah Abl al-Sunnah wa alJamā'ah. Jakarta: Pustaka Imam Asy-Syafi'i, 2006.

Meijer, Roel (ed.). Global Salafism: Islam's New Religious Movement. London: Hurst and Company, 2009.

Mubarak, M Zaki. Genealogi Gerakan Radikal Islam Indonesia: Gerakan, Pemikiran dan Prospek Demokrasi. Jakarta: LP3ES, 2003. 
Ostebo, Terje. "Growth and Fragmentation: The Salafi Movement in Bale, Ethiopia", dalam Roel Meijer (ed.), Global Salafism: Islam's New Religious Movement. London: Hurst and Company, 2009.

Ramadhani, Abdul Malik. 6 Pilar Dakwah Salafiyah. Jakarta: Pustaka Imam Asy-Syafi'i, 2000.

Tempo.co. "Dua Penyebab STAI Ali Bin Abi Thalib Didemo", 8 Februari 2015.

Tribunjatim.com., 4 Agustus 2018.

'Ubaylān (al), 'Abd Allāh b. Șālih "Pelajaran tentang Manhaj Salaf', Adz-D zakbiiroh al-Islamiyyah, Vol. 1, No. 05, 1424/2003.

\section{Wawancara}

Ali Musri. Wawancara. Jember, 20 Agustus 2018.

Arifin Badri. Wawancara. Jember, 20 Agustus 2018.

Fadlan Fahamsyah. Wawancara. Surabaya, 26 September 2018.

Mubarak Bamualim. Wawancara. Surabaya, 26 September 2018. 